\title{
Corruption and Governance in South Asia
}

\section{(in South Asia 2009 published by Europa publications)}

\author{
General Survey
}

\author{
Corruption and Governance in South Asia
}

\section{Mushtaq H. Khan}

Since the early 1980s the problem of corruption and issues of governance have come to the fore in all South Asian countries. Internal public concern over corruption, and pressure from international agencies, such as the World Bank and the IMF, and from bilateral agencies alarmed by the misuse of aid, has been growing. Closely linked to the issue of corruption is a wider set of concerns regarding governance, including the operation of the judicial system, the stability of property rights, and the functioning of democracy. Corruption has been foremost on the agenda, out of all these issues, as it is widely perceived to be not just a problem in itself but also an indicator of other failures of governance. In response to internal and external pressures, political parties in South Asia have adopted anticorruption programmes, although usually only as populist slogans or to attack their opponents. Furthermore, citizens' groups and local and international non-governmental organizations (NGOs) have led intense campaigns and, significantly, a mainstreaming of anti-corruption policies by the World Bank and other international agencies has occurred. However, the problem of corruption persists in South Asia, as measured by the intense public debate on and media coverage of corruption, the ongoing concern of international agencies and investors, as well as the poor showing of these countries in international rankings of corruption indices constructed by the NGO Transparency International and other such agencies. On the other hand, the debate on governance in South Asia has also been very narrowly defined, with insufficient attention being paid to many important aspects of growthenhancing governance capabilities.

Since the early 1980s prime ministers and presidents in Bangladesh, India and Pakistan have been legally implicated in, and sometimes even convicted of, corruption, and in Nepal and Sri Lanka prime ministers have been regularly accused of corruption by their political rivals and the media. Provincial, state and local governments in all South Asian countries have also been accused of being equally corrupt, with a number of flamboyant chief ministers in India acquiring an international reputation for corruption. The form of government also seems to have had little effect on the magnitude of corruption, with both democracies and authoritarian regimes displaying equally high levels of corruption. Public disclosures of large-scale corruption in Bangladesh, India and Pakistan have often been dominated by major irregularities in government procurements. While in the past public-sector industries attracted the most attention for nepotism and clientelism, recently a number of spectacular corruption-related scandals and crises in privatization deals and the regulation of financial markets have been exposed. At a lower level, government functionaries of all types are widely engaged in corruption; police, customs, land registration and irrigation officials receive frequent negative attention in the media. In public opinion surveys, police forces throughout the Indian subcontinent are often accused of being the most corrupt agencies, not necessarily because they appropriate the greatest amount in bribes but because for most people their corruption is the most visible and irksome on a daily basis. This qualitative and journalistic evidence of widespread corruption in South Asia is supported by surveys of public perceptions of corruption that are collated by the World Bank to provide indices for the 'control of corruption' in different countries. These indices are constructed in such a way that they range from -2.5 (the highest level of corruption) to +2.5 (the lowest level of 
corruption), with the average of all countries' indices being 0.0. Below each index listed in the following table appears the standard error, which shows the degree of confidence given the variation in the indices available for each country.

\section{Control of Corruption Index for South Asia}

(range: -2.5 to +2.5 , standard error shown in brackets)

\begin{tabular}{lcccccc} 
Country & 1996 & 1998 & 2000 & 2002 & 2004 & 2008 \\
Afghanistan & na & na & -1.56 & -1.32 & -1.33 & -1.64 \\
& & & $(0.44)$ & $(0.27)$ & $(0.21)$ & $(0.21)$ \\
Bangladesh & -0.47 & -0.40 & -0.60 & -0.95 & -1.09 & -1.1 \\
& $(0.24)$ & $(0.21)$ & $(0.16)$ & $(0.14)$ & $(0.14)$ & $(0.15)$ \\
India & -0.31 & -0.17 & -0.25 & -0.36 & -0.31 & -0.37 \\
& $(0.17)$ & $(0.13)$ & $(0.15)$ & $(0.13)$ & $(0.12)$ & $(0.13)$ \\
Maldives & na & -0.55 & -0.45 & -0.05 & 0.12 & -0.6 \\
& & $(0.37)$ & $(0.24)$ & $(0.22)$ & $(0.24)$ & $(0.26)$ \\
Nepal & -0.28 & -0.59 & -0.56 & -0.37 & -0.61 & -0.68 \\
& $(0.47)$ & $(0.27)$ & $(0.20)$ & $(0.18)$ & $(0.16)$ & $(0.18)$ \\
\multirow{2}{*}{ Pakistan } & -0.98 & -0.76 & -0.80 & -0.81 & -0.87 & -0.77 \\
& $(0.23)$ & $(0.18)$ & $(0.16)$ & $(0.15)$ & $(0.14)$ & $(0.15)$ \\
\multirow{2}{*}{ Sri Lanka } & -0.23 & -0.24 & -0.09 & -0.13 & -0.16 & -0.15 \\
& $(0.24)$ & $(0.21)$ & $(0.15)$ & $(0.14)$ & $(0.14)$ & $(0.15)$
\end{tabular}

Source: Kaufmann et. al. (2009)

Note: na $=$ not available

These indices should be interpreted carefully as they are based on subjective perceptions and in addition the scores are normalized so that the average of the scores of all countries is set equal to zero every year. Therefore the improvement in the index for a particular country does not necessarily mean that corruption has reduced in that country, it could be that corruption has worsened in other countries or the sample of countries has changed. However, to the extent that these scores are comparable over time, they suggest that official policies and pressure from NGOs and civil society had minimal effect on reducing corruption between 1996 and 2008. There have been small improvements in the index over this period in Pakistan, Sri Lanka, Afghanistan and Bhutan, but even in these cases the improvements were not significant, given the standard error in the indices. In the other South Asian countries the corruption measure worsened. There is some concern, particularly in Bangladesh, about whether the decline in these subjective indicators in recent years reveals the changing sensitivities of respondents rather than real changes in the degree of corruption. Nevertheless, while subjective perception indices may not reflect true changes in the degree of corruption, they do reveal growing public disquiet with the slow progress in dealing with the problem. Sri Lanka, which has a somewhat higher per capita gross national income than its neighbours, the corruption index was correspondingly better. However, even in Sri Lanka, corruption has become one of the main issues to dominate accusations and counter-accusations made by government and opposition parties. The Maldives and Bhutan had the lowest recorded levels of corruption in the Indian subcontinent, and were the only South Asian countries with corruption indicators that were positive in 1998, which means that they had corruption rankings better than the global average. By 2007, however, the Maldives had reverted to 
the South Asian pattern, suggesting that the early results could have been the result of lower public awareness of corruption as a problem in the islands, rather than a significant real change in the degree of corruption in less than a decade. Indeed, the standard errors again suggest that there may have been little real change in corruption in this country. Afghanistan has consistently had the highest corruption indicator in South Asia, reflecting the continuing role of warlords and criminality in its economy. Here the corruption is largely of a different type and magnitude, compared with its neighbours, since a nation-wide state structure does not yet exist.

The extent of corruption in South Asia has led to wider concern regarding poor governance, which in turn is responsible for poor economic performance, persistent poverty, the subversion of democracy and the inability to attract sufficient foreign investment. However, in assessing corruption in South Asia, it is desirable to remember that corruption is rife in all developing countries, regardless of their economic growth rates; indeed, the level of corruption is strongly connected to the country's level of development. Generally, the poorer and less developed a country is, the more it suffers from corruption. This is even true of high-growth developing countries such as the Republic of Korea in the 1960s or the People's Republic of China in the first decade of the 2000s. This cross-country evidence suggests that studying the aggregate evidence of corruption is likely to be misleading, since even rapidly growing economies experience relatively high levels of corruption in their nascent stages. Clearly, it is necessary to distinguish between different types of corruption and to identify why the more damaging types predominate in less dynamic economies such as those found in South Asia. This will also help to assess the likelihood of success for specific anti-corruption strategies.

\section{A Typology of South Asian Corruption}

Corruption can be defined in various ways, but it is typically understood to mean a violation of law by public officials for private gain. The private gain of the public official usually involves accepting bribes, which constitutes a direct violation of the law. In addition, the public official typically offers in exchange decisions or services that may be legal or illegal, and beneficial or damaging for society. The services that the public official offers can be legal if they are legal entitlements but beneficiaries have to bribe to get these entitlements. On the other hand, corruption may also result in further illegal acts, for instance through the provision of a proscribed service and/or the subversion of state policies in a way advantageous for the bribe-payer. In addition, the economic effects of these interventions can be socially damaging or otherwise. As a result, four different 'types' of corruption can be identified depending on whether the underlying intervention or service provision that follows is legal or illegal, and whether it is socially beneficial or damaging. While the bribery part of corruption is always damaging in the sense that time and resources are used up, the net effect of corruption also depends on the underlying intervention or service provision associated with the corruption. Moreover, unlike taxes, the payment of a bribe does not guarantee the promised service or decision, and there is often little redress if the public official taking bribes does not deliver. In addition, corruption can have important indirect effects on business confidence and thus on investments. For instance, corruption could potentially result in sudden changes in government policy or in the reallocation of property rights, thereby adversely affecting the investment climate and increasing the overall costs of corruption. However, while bribery always imposes a cost on society, the net economic effect of corruption also depends on the type of intervention or subversion of policy that is achieved as a result of the bribe. Violations of useful and necessary laws are clearly damaging for the economy, and examples of such corruption are not difficult to find in South Asia. In these cases corruption is unquestionably damaging for the economy. However, there are also many violations of the law in developing countries that may not necessarily be socially damaging. For instance, emerging capitalists might have to navigate around politically necessary but restrictive laws, or necessary interventions might exist that have not yet been legally sanctioned. In some cases these interventions cannot be legally sanctioned for political reasons even though they are essential for maintaining political stability or economic growth. In these cases, the economic effects of corruption are anomalous; accordingly, 
corruption could be associated with either stagnation or growth. The distinction between types of corruption is important in order to understand both the economic and political effects of corruption and the appropriateness of different anti-corruption strategies. It is possible to distinguish between at least four types of corruption in South Asia, based on whether the underlying interventions are potentially necessary for economic or political reasons, and whether the law allows these interventions. This classification is shown below.

i) The underlying interventions are required for economic development or political stability and are legally permitted: the corruption associated with these interventions may be associated with growth or stagnation depending on the extent to which the necessary interventions (market regulation, promotion of industries, subsidies for political stabilization) are subverted. If the underlying interventions remain developmental, corruption here operates mainly as a tax. If however the corruption affects implementation such that the allocation of resources stops being developmental, corruption could be associated with very negative outcomes. Anticorruption policy here should seek to improve implementation and reduce corruption, but not to remove the interventions.

ii) The underlying interventions are required for economic development or political stability but are legally prohibited: In this case since the interventions are by definition illegal or extra-legal, all efforts to influence government are likely to involve corruption. These types of corruption may again be associated with growth or stagnation depending on the nature and extent of these interventions (discriminatory benefits for powerful groups to maintain stability, preferential access to resources for emerging capitalists). Policy in these areas should focus on gradually legalizing necessary interventions so that these can be transparently regulated and on reducing damaging interventions.

iii) The underlying interventions are damaging for economic development or political stability but are legally permitted: here corruption is associated with attempts to avoid dysfunctional interventions (unnecessary paperwork and permissions, protection of inefficient industries) and corruption is always associated with negative effects. Corruption can paradoxically reduce the damage done by bad regulations and laws, but the overall effect of the regulation and the corruption is always negative compared to the situation where the damaging intervention did not exist. Policy should therefore seek to remove the damaging state 'functions' (through liberalization and privatization). This has been the focus of mainstream anti-corruption strategies, but they actually cover only a small part of the range of corrupt activities.

iv) The underlying interventions are damaging for economic development or political stability and are legally prohibited: here public officials violate the law in damaging ways for their personal benefit and the corruption associated with these types of 'interventions' are primarily theft and predatory extortions by public officials. While some instances of predatory corruption can be found in all South Asian states in the form of theft and fraud by public officials, this type of corruption only begins to predominate in failed or failing states where armed groups can extort from society regardless of their effects on political stability or economic performance. In order to tackle this type of corruption, effective policy has to focus on strengthening the State and in extreme cases of state failure, to strengthen the centralized coercive power of the State.

The first type of corruption explained above is associated with interventions that are potentially necessary for the economy or polity, and are allowed and regulated by law. Examples of these interventions are subsidies to maintain political stability, different types of schemes to help domestic industry catch up with foreign competitors, and the regulation of financial markets. Although economic liberalization has been taking place in all the major South Asian countries since the 1980s, a wide range of interventions remains important and necessary for economic growth and political stability. 
Individuals and groups might become involved in corrupt activity to subvert the implementation of these interventions. However, here the problem is not the interventions themselves, but the State's lack of capacity to implement them. Here, anti-corruption policies should concentrate on strengthening the capacity of the State to enforce the necessary policies and development strategies. There are a number of critical governance capabilities that need to be strengthened in this area to enhance or sustain the growth prospects of these economies, but this is one area of governance that has received far less attention than it deserves.

The second type of corruption, concerning necessary interventions that are not-or cannot beregulated by law, is much more problematic. In South Asia, much of the widespread political corruption that involves allocating resources in partisan ways to maintain political stability is an example of this type of corruption. Similarly, interventions to accelerate and promote emerging capitalism in countries where domestic capitalism is weak often have to be partisan and cannot be recognized in law. These interventions are very likely to result in corruption, since they cannot be explicitly recognized in law for political reasons. Attempts to target this form of corruption directly have proved futile, since such action threatens to damage the fundamental interests of the State and is therefore never effectively implemented. A more feasible, albeit limited, policy would be damage-limitation in the short term and, in the longer term, ensuring the country's rapid progress to a position where it would be possible to legalize some of these interventions, or achieving political and economic development so that these interventions are no longer essential. Unfortunately, this is the area in which feasible anti-corruption strategies in South Asia are most lacking.

The third type of corruption has received more attention than the other types. It comprises corrupt acts associated with laws that enable interventions in contexts where the interventions themselves are not required. Typical examples of these are tariff protection for industries that do not have the potential to achieve the productivity of their competitors; or excessive regulation and requirements of permissions that have no purpose except to enable bureaucrats to extract bribes from businessmen. South Asian countries have been well known for these types of regulations. These dysfunctional interventions not only cause direct economic damage, but also create secondary damage, as entrepreneurs use corrupt means in an attempt to gain monopoly profits or to circumvent futile restrictions. In these circumstances the liberal prescription of liberalization and privatization is most appropriate, combined with direct anti-corruption measures. However, this is not the most important type of corruption in South Asia, and an excessive focus on this type hitherto has hindered, rather than aided, the development of feasible anti-corruption strategies.

Finally, the worst type of corruption is the fourth one, which is most prevalent in areas where the enforcement of social order by the State has broken down completely. Illegal interventions take place that do not serve any economic or political purposes for any groups apart from the avaricious 'officials' involved in this form of corruption. Thus, this type of corruption is based solely on the coercive power of small groups of officials to extort from the public. While there are aspects of such extortions in every South Asian society, it is only in Afghanistan that it takes on significant proportions.

\section{Political Corruption}

Political corruption refers to the corruption operated by politicians. Political players can be involved in all types of corruption, but political calculations are particularly important for the second type of corruption where corruption is directly involved in the political process. In all South Asian countries, political corruption can be traced from the highest levels of the political establishment, down to the lowest. Unsurprisingly, it has proved difficult for the political system to engage credibly in anti-corruption activities lower down the hierarchy. In democratic Bangladesh, India, Nepal and Sri Lanka, prime ministers have been frequently accused of corruption, and have sometimes been convicted of criminal offences, as have their authoritarian counterparts in Bangladesh and Pakistan during military or authoritarian regimes. In the latter countries, where there have been cycles of 
democracy and dictatorship, no significant long-term difference is observed in the extent of corruption under either type of regime. This evidence compels us to question the widespread belief that corruption is caused by the lack of accountability of public officials. In fact the evidence from South Asia shows that electors are very aware of the corruption and even criminality of their political representatives but still vote for corrupt politicians, often at the expense of 'clean' campaigners who occasionally stand against them.

In 1997 the Indian Election Commission conservatively estimated that 40 members of parliament and 700 state assembly representatives in India, altogether equal to $10 \%$ of all legislators, had been convicted of serious criminal offences or faced serious criminal charges, ranging from extortion to murder. In the 2002 Indian state elections as many as $20 \%$ of the candidates in certain states were convicted criminals or had been charged with crimes. The true number of legislators involved in crime is likely to be considerably higher than these figures, which account for legislators who have already been convicted or whose cases are being processed in the courts. It is fairly certain that many other legislators in the first decade of the 2000s are engaged in criminal activities without being indicted. It is also widely perceived in the Indian press and in opinion surveys that the proportion of criminals involved in politics is increasing. The visibility of political corruption reached a new level in India in July 2008 when the ruling Congress-led coalition Government achieved a narrow victory in the parliamentary vote of confidence precipitated by the Indo-US nuclear deal. Three opposition MPs of the Bharatiya Janata Party carried bags of money into the Lok Sabha and accused the ruling coalition of attempting to bribe them with Rs $10 \mathrm{~m}$. to boycott the vote. Whatever the findings of the inquiry that was subsequently instituted, the incident was unprecedented and will be remembered as a particularly low point in the history of the Lok Sabha. In November 2006 an interim Government took power in Bangladesh and declared a state of emergency in January 2007. More than 200 politicians, including the heads of two previous governments, were arrested on charges of corruption. Several prominent politicians were convicted, but in the majority of cases sufficient evidence was not available and many of the cases were dropped. By late-2008 both the arrested former prime ministers had been acquitted marking the end of the anti-corruption drive. One of the released former prime ministers was then elected in the December 2008 elections. The frontal attack on corruption by the emergency Government in Bangladesh was badly conceived because it did not distinguish between the different types of corruption discussed earlier and did not prioritize a limited number of objectives. By attempting to do away with all corruption even those associated with the operation of the political system it set itself up to fail. At best it may prove to have some lasting if limited impact on the operation of political parties in the future. Despite all this, the freedom of the media in reporting political corruption in India is comparable to advanced countries, and even in Bangladesh, Pakistan and other South Asian countries, the evidence of corrupt activity by leading politicians is well known and freely available.

When asked to explain their voting decisions, South Asian voters frequently report that they vote for 'mafia-style' politicians because they have proved able to deliver resources and security to powerful local constituents, who in turn provide the organizational weight to ensure electoral victories and enforce political order. The logic driving this pattern of politics can be better understood once the constraints facing the delivery of services and the provision of security are studied. As is the case in other developing countries, South Asian states generally lack the fiscal resources to perform these functions effectively because their central budgets are in structural deficit; funds are not available to provide even the most essential services adequately. In these circumstances conflicts over resources are intense; 'intermediate-class' groups often organize themselves around factional symbols, based on ethnicity, religion or caste in competing for these resources. Politicians subsequently find that they can only be successful if they offer selective benefits to at least some of these effectively organized factions. Since providing preferential benefits to some but not others is not legal, the degree to which the politician follows the law is not of great concern to his or her most critical supporters. Indeed, a truly honest politician would find it impossible to secure any organized support from these critical 
factional groups, and without their support, power cannot be attained. The growing malaise of criminality in politics and the rise of factional politics in South Asia is at least partly due to the 'prisoner's dilemma problem', where credible politicians are excluded by the competition from less scrupulous political entrepreneurs who can offer more to factions that are in search of a patron. Thus, while democracy is desirable in itself, it has anomalous effects on the extent of corruption. A long-term change in this pattern of politics is unlikely before economic development has proceeded to the point where the central budget can provide sufficient resources for honest politicians to stay in power through providing widespread service-delivery and redistribution. Meanwhile, in the first decade of the 2000s a symbiotic relationship between politicians who use political power for personal enrichment and the enrichment of their close allies, and the powerful social factions, which require access to resources, jobs and contracts (all services that honest politicians cannot possibly provide) remains a dominant characteristic in South Asian politics. This would explain why all major political parties regularly accuse each other of corruption while eagerly recruiting criminals who can offer resources and secure the support of powerful factions. It also explains why ordinary citizens criticize their politicians for being involved in corruption while simultaneously voting for corrupt leaders who they think are most likely to protect their constituency and provide their own faction with disproportionate benefits.

South Asian political corruption is largely of the second type (see above), since the current strategies of maintaining political power cannot be legalized, and the approach of legitimately maintaining power through the provision of generalized benefits is not viable given the level of economic development. This type of political corruption may eventually result in sufficient political stability for rapid economic growth to take place, as did happen in some East and South-East Asian countries. This would, subsequently, permit the growth of formal budgetary redistributions and service-delivery to take place, thereby allowing more honest politics and politicians to emerge in the future. However, in South Asia the continual emergence of new groups and factions has meant that, over time, politics has become more factional, fragmented and crime-driven. As this continues to happen, the risk is always present that more and more political corruption will convert into the fourth type, where the criminal activities of politicians enrich only themselves, using the coercive force of private mafias to extort from the rest of society. In Afghanistan in the first decade of the 2000s an extreme version of this fragmentation exists, where regional military commanders can extort from society and engage in crime and the central State continues to find it difficult to constrain their activities. However, this degree of social fragmentation and the use of coercive force should be distinguished from the clientelist politics of other South Asian countries, where local mafias have had to engage in a political process of suborning powerful groups and forming political coalitions that, however imperfectly, has maintained some form of social stability. But in all these cases, where political corruption is driven by the demands of politically powerful groups, greater transparency, democracy or civil society participation would be unlikely on their own to have a significant impact on reducing this type of corruption in South Asia. There is no reason to suggest that democracy or transparency would reduce the political requests of powerful groups. Indeed, the focus on greater democracy and transparency as a method of countering corruption in Bangladesh and Pakistan has yielded very disappointing results. In Bangladesh a decade of democracy witnessed a rapid rise in political corruption. The extreme measures adopted by the military-supported emergency Government in 2007-08 in Bangladesh, including the arrest of leading politicians from all major political parties on corruption charges, reflects frustration with this democratic process. These measures were initially widely supported by the general public. However, precisely because political leaders do deliver to critical constituencies, it is not credible that they can be incarcerated for long. As a result, the emergency Government found that it was not possible to obtain significant testimonies and evidence in court from individuals who held this information, possibly because those who could provide convincing testimony were hedging their bets. Consequently, the majority of corruption cases collapsed. This experience shows that a sound analysis of the drivers of political corruption is required before undertaking large scale anti-corruption campaigns. A much more narrowly focused attack on a 
small number of high-ranking politicians may have proved more successful in signalling that there are limits to the extent of political corruption that would be tolerated by other social constituencies such as the army. The only significant immediate result of the Bangladeshi anti-corruption drive was a decrease in business confidence, since many businessmen were charged with tax evasion and the bribery of politicians. The sole positive note is the possibility that this experience will set some limits to the types and extent of corruption that subsequent governments will engage in. The irony is that the real problem that led to the imposition of the state of emergency in January 2007 was not directly due to political corruption but was caused by a political impasse between the major political parties where the ruling party was engaging in activities that the opposition considered would compromise its ability to win the forthcoming election. In Pakistan the return of military rule in 1999 appeared to reduce corruption, although the sustainability of this development proved questionable once it became necessary for the Government to begin constructing wider political support bases to remain in power.

The greater fiscal capacity necessary for governments to provide legally the demands of its constituents will be generated only once the region undergoes longer-term economic development. In the mean time, the rapid growth and negative effects of political corruption could conceivably be reduced through the development of large, inclusive political parties that aim to impose social discipline in order to achieve long-term development goals. Such parties would not entirely curb political corruption, but might succeed in countering the growing fragmentation and factionalization of politics across South Asia. It is not surprising that the Indian states that perform relatively better than others are those that are run by disciplined and centralized parties. To some extent the resurgence of the Congress Party in the 2009 Indian elections represents a tiredness of the electorate with highly fragmented coalition politics and the improved budgetary position of the Indian state that allows parties like the Congress to offer more to poorer citizens through fiscal redistribution. However, whether the 2009 elections will mark a step decline in the fragmentation of Indian politics along patron-client lines will depend on how effectively Congress can deliver redistribution through fiscal mechanisms rather than conventional patron-client networks over the next five years. Even in the much smaller and more ethnically homogenous countries of South Asia, national parties have become loose coalitions of factions, with each faction demanding ever greater rewards for not defecting to the opposition. This explains the escalating cost of politics in these countries and the escalating cost of political corruption.

Further, albeit limited, progress towards mitigating the extent of political corruption would also be possible through the legalization of large donations to political parties. Allowing political parties to pay legally for some of their expenses during and after election campaigns would not remove the problem entirely, since political organizers demand much more than the cost of organizing elections in exchange for their support; nevertheless, it would reduce the need for political parties to engage in corrupt or criminal activities simply to raise funds for election campaigns. In Bangladesh and India politics is increasingly funded by so-called 'black money' (money generated by crime or from 'grey' activities that are not declared to avoid paying tax). It has been estimated that the black economy has burgeoned to approximately one-third of the size of the official economies in these countries. However, attempts to regularize election funding have been blocked by other political considerations. In India the proposed Election and Other Related Laws Bill was introduced in Parliament in 2001-02 to provide, among other measures, income tax exemptions for private and corporate donations to political parties. This legislation was stalled in Parliament, partly because it challenged the dominant political ideology shared by all major parties that rejects any 'disproportionate' political influence for the rich. Aside from ideology, in an emerging economy it is also problematic to legalize donations from such sources when much of the wealth of this emerging rich élite is tainted by association with 'sharp practices' (a large proportion of the 'new rich' has engaged in corrupt activity, such as illegally obtaining land, or using political connections to gain lucrative contracts). However, although there are problems surrounding political fund-raising reform, the current system is far worse. Thus, when the Indian Election Commission attempted to prohibit criminals from contesting elections, the Government 
also delayed this proposal. The Indian Election Commission has imposed limits on election spending by candidates, but these restrictions have proved difficult to enforce; in any case, the limits currently apply only to spending by individual candidates and not to expenditure by their political parties. Indeed, rather than showing any signs of being constrained by these attempts, it is widely perceived that election expenditure is increasing. However, under a new law enacted in 2003, all candidates for election now have to submit details of any criminal case pending against them, a record of their assets and liabilities, and their educational qualifications. These measures may help to encourage political parties not to field questionable candidates, but it is not clear how reported assets and liabilities can be cross-checked to confirm their accuracy. Indeed, it has proved difficult to make any progress on taking action against the more than 700 incumbent legislators who actually have criminal cases pending against them.

Similar tendencies of entrenched political corruption are observed in Bangladesh, Pakistan, and other South Asian countries. In 2002 the Pakistani President, Gen. Pervez Musharraf, enforced a strict electoral rule barring politicians convicted of criminal offences from contesting elections. However, critics argued that the real intention behind the enforcement of this rule was to exclude the two prominent civilian political leaders of the country from standing against the military regime in elections held later that year. The possibility of enforcing such a rule under a future civilian administration is arguable, given the pressures outlined above. Even the National Accountability Bureau (NAB) in Pakistan, which has achieved considerable success in recent years in prosecuting public officials and retrieving their misappropriated funds, is considered to be an agency of the armed forces rather than an independent authority. It is significant that the military (and the judiciary) are excluded from its mandate. Although President Musharraf came to power ostensibly to save the country from the corruption of the political élites, the centralization of power in the executive arguably created greater instability in Pakistan. In mid-2007 the Pakistan judiciary achieved a significant victory over the executive headed by President Musharraf when it succeeded in reinstating the Chief Justice, Iftikhar Mohammad Chaudhry, who had been suspended from his post by the President. This case was expected to have an impact on broader questions of governance in Pakistan and may even be considered to have marked the onset of the transition to civilian rule and greater checks on executive power. Following a period of serious political unrest, a democratically elected Government came to power in Pakistan in February 2008 and, under threat of impeachment, President Musharraf resigned from the presidency in August. In Bangladesh an Independent Anti-Corruption Commission (IACC) was established in 2004 with the power to investigate allegations of corruption against any public official without first having to seek government permission, as was previously the case; in practice, however, the IACC proved to be fairly ineffectual. The emergency Government that took power in 2007 reconstituted the Anti-Corruption Commission in Bangladesh and acceded to the United Nations Convention against Corruption; however, the effectiveness of these measures will take some time to assess. In November 2007, in a move that was intended to strengthen the power of the judiciary to put on trial and convict corrupt politicians and bureaucrats, the emergency Government also implemented an eight-year-old ruling of the Supreme Court that demanded the formal separation of the judiciary from the executive. Again, whether the implementation of this measure will actually enable the judiciary to prosecute the most serious cases of political and administrative corruption remains to be seen. In India the Central Vigilance Commission is regarded as autonomous, but its remit covers only state employees and not politicians. Most importantly though, if it is accepted that much political corruption in these countries is entrenched and 'society-driven', the task of any anti-corruption commission would at best be partial in the short term, and this would make it difficult for it to defend itself convincingly as non-partisan. India's great advantage over its smaller neighbours is that paradoxically its very size and complexity make it impossible for any one faction to monopolize power for too long, and electoral competition imposes natural checks on the degree of appropriation that factions in power can get away with. Citizen activism in India, in the form of civil society election watches' which publicize the affidavits on criminal cases, assets and liabilities submitted by candidates, has played a role in this context. 


\section{Bureaucratic Corruption}

Corruption committed by bureaucratic officials in South Asia ranges from the petty corruption of police officers collecting nominal bribes for minor traffic offences, to multi-million dollar bribes collected by senior army officers and defence officials in major military contracts. Once again, bureaucrats are likely to be involved in all types of corruption. Much bureaucratic corruption is of the first and third type discussed earlier: there are legal regulations and services provided by the state, some socially beneficial and others not, and corruption is often involved in the evolution and management of these interventions. Some bureaucratic corruption is also intimately connected with political corruption, the second type of corruption discussed earlier. At the highest levels politicians and bureaucrats have to collude in large-scale corrupt activity that provides resources or creates political support for politicians. These different types of bureaucratic corruption are interrelated; the persistence of low-level bureaucratic corruption cannot be understood without taking into account the absence of political will to combat corruption on the part of high-level political office-holders who are themselves vulnerable to attack for their own corruption. For example, newspapers in South Asian countries frequently report stories of police forces being prevented from prosecuting heads of criminal organizations or of crime cartels protected by powerful politicians. Finally, some bureaucratic corruption is also of the fourth type, predatory corruption or theft in contexts where the central state has lost control over individual officials.

A common argument in South Asia is that low bureaucratic pay contributes to high levels of bureaucratic corruption. This is undoubtedly true, but it is not clear that raising bureaucratic salaries would necessarily reduce corruption. Higher-paid bureaucrats would only consider refraining from corrupt activity if it were possible to identify the perpetrators and dismiss those who were occasionally caught. However, if the political capacity to attack bureaucratic corruption is absent, higher salaries may have little effect. Furthermore, bureaucratic corruption takes many different forms in South Asian countries, and there are instances of each of the four types identified above. First, the misappropriation of funds by bureaucrats engaged in the operation of legally recognized regulatory structures that have necessary or useful economic or political functions is common. These include structures established to regulate markets, promote industry and agriculture, and manage subsidies and redistributions that aim to maintain political stability. Although these systems of state intervention or regulation are beneficial for society, they inevitably confer benefits on some and costs on others and are therefore susceptible to either the attempts of bureaucrats to extract a share of the benefit by demanding bribes from intended beneficiaries, or attempts by non-eligible recipients to obtain some of these benefits by offering bribes, or both. The degree to which state policy is subverted and the magnitude of the bribes determines whether the act of corruption has encouraged or discouraged reasonable economic performance or not. If bureaucrats were to implement what was intended by policy and then extract bribes, the result would be much more favourable than if they were to accept a bribe to subvert what was intended.

Unfortunately, in many parts of South Asia bureaucratic corruption has seriously subverted numerous critical state functions, including regulatory functions and the protection of property rights. For instance, corrupt activity has subverted the operation of welfare subsidies and of policies to encourage industrialization or regional development. Factories that never produce anything continue to receive production subsidies or are permitted to roll over their debt to publicly owned banks, for example. A further problem is the absence of a functioning judicial system. In South Asia many civil cases take more than a decade to resolve. The judicial process is susceptible to manipulation: those who want to prevent a judgment can pay relatively small bribes on a regular basis to delay a case or force an adjournment. Some attempts have been made to address these problems through state withdrawal in the form of liberalization and privatization. However, progress has been slow and in the case of effective state functions, interventions and regulations, state withdrawal is not a solution. Some cases of corruption in the awarding of contracts and in public purchases have elements of 
outright theft and predation. In April 2009 India's Central Bureau of Investigation (CBI) uncovered a potentially broad-ranging network of officials involved in significant corruption in the granting of defence contracts. One of the officials under investigation was the recently retired head of the Ordnance Factory Board (OFB), making him the highest ranking Indian defence official to have been arrested on graft charges. A number of international arms manufactures including Israel Military Industries Limited and a number of Indian companies were blacklisted as potential participants in the racket once the investigation began. As India becomes a major international arms purchaser, the stakes in this game have risen significantly, and it is unlikely that such high-ranking officials could have been acting entirely on their own.

Strategies of liberalization and privatization were introduced in the major South Asian countries from the 1980s onwards; an acceleration of liberalization occurred in the 1990s. In India the average tariff rate was reduced from $87 \%$ in 1990 to $25 \%$ by 1998 . Licensing of industries and controls over imports were almost entirely removed. In Bangladesh and Pakistan the nationalization process that took place in the 1970s was reversed through extensive privatization programmes. Some of the restrictions that were removed had no potentially positive function, and little was lost as a result. However, other parts of the regulatory structure had been intended to accelerate the development of local entrepreneurial capacity through industrial policy and protection, or to maintain internal regional and social balance, and here state withdrawal was potentially damaging. Even the privatization of large enterprises in Bangladesh and Pakistan, in the absence of effective regulatory structures and safeguards, often resulted in inefficiency and subsidy appropriation in the private sector replacing the inefficiency and deficits of the public sector. In India liberalization of financial markets resulted in dramatic allegations in 2001 of widespread share price manipulation in the stock market and multimillion dollar irregularities in India's largest investment fund, the Unit Trust of India. Moreover, the withdrawal of the State from traditional redistributive and regulatory functions has resulted in the development of illegal redistributive mechanisms governed by the type of criminal organizations described in the section on political corruption. The growth of the private sector has created the need for significant regulatory capacities that are still very weak. Indian regulators were caught entirely off guard by the massive fraud in late 2008 in Satyam Computer Services, one of India's largest IT firms. Its reported operating profits of $\$ 137 \mathrm{~m}$. turned out to be fraudulently overstated by a factor of more than 10. Its CEO admitted this had been going on for years though the company was audited by PricewaterhouseCoopers and had independent directors on its board. Finally, in the case of the police force and judiciary, state withdrawal is not even possible. In fact, the appropriate response in all cases of corruption associated with the subversion of essential state functions is to strengthen state capacities. Progress on this front has been limited across South Asia. If the State had the capacity to enforce decisions that were beneficial for society, bribery committed by public servants even when it took place would be undesirable but would not subvert development goals completely. However, where corruption undermines the enforcement of necessary regulations, the results are much more detrimental. This is an important aspect in the difference between corruption in economies where high growth is sustained and those where it is vulnerable.

The second type of bureaucratic corruption that emerges because a legal framework to enforce a large number of necessary state actions or decisions does not exist is more prevalent and causes greater problems for government anti-corruption policy. In the same way that political stability in South Asia is partially dependent on powerful factional groups receiving disproportionate benefits, rationing scarce resources often requires disproportionate amounts of resources being allocated to the rich, or to emerging capitalists. Although developing countries are often legally committed to granting equal access to public resources to all citizens, if public resources become very scarce, not only will the rich be willing to pay a high price to gain privileged access, but it may also be desirable to give emerging capitalists privileged access to some resources to accelerate growth. However, state agencies involved in the allocation of public resources, such as land rights, credit, and other scarce resources, or indeed any aspect of regulation or service-delivery, are legally bound to operate according to rules that 
are far removed from the reality of stark differences in the purchasing power, economic potential, social status or political influence of claimants. In all these cases, alternative rationing devices are used in practice, based either on willingness to pay or political power. This kind of corruption is ubiquitous, ranging from the illegal sale of formally free hospital services, to the allocation of government land for new developments in exchange for 'contributions' to political parties or politicians. These types of corruption are difficult to deal with because state capacity alone is not the issue. The real obstacle is that, for political reasons, realistic criteria for resource allocation cannot be legally recognized. Some legal changes could be enforced to improve the situation, for instance introducing a nominal fee for some services. In most cases, however, charging would not solve the problem because the market price that would balance demand and supply would not be politically acceptable. In any case, it is not desirable that all public resources should be allocated through the market; however, where resources are publicly allocated on the basis of need or any other criteria, sufficient resources have to be available to meet the demands from all those who satisfy these criteria. Since this requirement is generally not met in developing countries, there may be no alternative but to endure some of this corrupt activity until the economy is developed enough to provide the State with sufficient funds to allocate resources in the way expected by law. In the mean time, the only policy response would be to strengthen state capacities and prevent egregious violations, although these actions alone clearly would not entirely remove this type of corruption.

Much of the anti-corruption strategy advocated by international agencies is dominated by the assumption that the third type of corruption is the dominant force in South Asia. This is the corruption associated with unnecessary legislation that hampers the operation of markets and creates opportunities for corruption among relatively poorly paid public officials. This type of corruption is associated with entirely unnecessary and damaging state interventions in the form of legislation, and could easily be dealt with by removing such restrictions. It is not hard to find many examples of excessively restrictive and apparently superfluous regulations in all South Asian countries. These include requirements to fill in many different forms for all kinds of permissions, which are then subject to inordinate delays. Whether it is an application for a passport or even an attempt to pay the correct amount of tax on time, the ordinary citizen faces endless delays and frustration. However, while this type of corruption is tiresome, it is only a part, and perhaps a small part, of the overall problem. The conventional policies of liberalization, privatization and greater accountability would appear to be the most relevant solutions to this type of corruption, but they may have little overall effect in either reducing corruption or mitigating its negative effects when we consider all types of corruption together. Moreover, many of the procedures of bureaucratic record-keeping, on which this type of corruption is based, are very difficult to change rapidly even with liberalization and privatization. After more than a decade of liberalization in a number of South Asian countries, the daily procedures of the bureaucracy have undergone some simplification, but a great deal more progress needs to be achieved. Furthermore, liberalization has added new regulatory burdens on the State with respect to financial markets and the corporate sector. Liberalized markets require strong and effective regulatory frameworks to operate properly, and the absence of adequate state capacity in these areas has created a paradox whereby corruption of the first type has increased in the aftermath of liberalization, as we saw earlier, even if corruption of the third type decreased. This explains why, when all types of corruption are studied together, journalistic reports or corruption perception indices record rapidly worsening corruption in South Asia in the 1980s, precisely when liberalization began to be introduced.

Finally, South Asian countries suffer to varying extents from corruption linked to extortion and other forms of crime. By definition, extortion offers no economic or political benefits to anyone other than the extortionists. There are many low-level examples of this type of extortion in all South Asian countries, particularly involving the police force, customs officials and, increasingly, criminal organizations associated with the political élite. Individuals without political connections and patrons, for example, are regularly forced to pay police officers bribes in exchange for a (temporary) end to harassment. Also, political mafias seize land from the weak, encouraged by the knowledge that the 
criminal justice system repeatedly fails the aggrieved. However, only in Afghanistan has the central state apparatus collapsed to the point where this type of corruption plays a significant role in the operation of the economy as a whole. In other South Asian countries there are pockets of extortion, but the State still retains enough centralized coercive capacity to limit its extent and is able and willing occasionally to use this capacity for the simple reason that extortion is a threat to the survival of the dominant élites and the State itself. It is not enough to expect democratic pressure to limit this type of corruption because unarmed citizens are not likely to be able to stop extortion through a democratic process. The coercive capacity of the central State is the critical determinant of the extent to which this type of corruption can grow. So far, at least, most South Asian countries still have central States that have been able to limit the uncontrolled growth of extortion.

\section{Prospects}

A large number of mechanisms have contributed to the entrenchment of corruption and the associated problems of governance in South Asian countries. Foremost among these has been the deep-rooted phenomenon of political corruption, and its growth over time, closely connected to the growing fragmentation of politics in South Asia. Since political corruption has become embedded in the democratic process, its removal is likely to be a long-term effort. Significant progress is likely to depend on economic development, which will allow the State to enhance tax collection and redistribute more resources legally in order to achieve political stability. As well as being an important issue in itself, the reduction of political corruption would also allow the diminution of different types of bureaucratic corruption. Bureaucratic corruption persists and thrives largely because the political élite is dependent on corruption for its survival. An examination of the significance of different types of bureaucratic corruption in South Asia shows why moves towards liberalization and privatization have had anomalous effects on corruption; in the short term, at least, the economic developments have appeared to contribute to an increase in corruption. The public concern with corruption and the role of the media and of NGOs have so far also had limited effects on reducing corruption even in the more democratic countries of South Asia. The more prevalent types of corruption in South Asia have particularly damaging effects on economic performance for a number of reasons. First, political fragmentation has always been prevalent in these countries and appears to be increasing. Greater fragmentation is likely to lead to more extensive political corruption and reduce the ability of central States to control the predatory tendencies of competing factions. Second, bureaucratic corruption has been particularly damaging in South Asia because state capacities have not been strong enough to prevent the subversion of essential state functions and interventions. Enhancing state capacities across the entire range of state functions is a particularly important task in all South Asian countries. Expanding state capacity is not likely to reduce all levels of corruption in the short term, but is expected to enhance governance by ensuring that economic development and political stability are achieved to a greater extent. Finally, the problem of military factionalism or warlordism (although it is prominent only in Afghanistan) has emerged in the milder form of mafia-dominated politics in all the major South Asian countries, drawing attention once again to the importance of enhancing central state capacities in all these countries.

Bibliography

Beg, Mirza Arshad Ali. Democracy Displaced in Pakistan: Case History of Disasters of Social Pollution. Karachi, Research and Development Publications, 1998.

Bhargava, B. S. Hawala Scam: Politics of Corruption. New Delhi, Arnold Associates, 1996.

Corbridge, Stuart, Williams, Glyn, Srivastava, Manoj, and Veron, Rene. Seeing the State: Governance and Governmentality in India. Cambridge, Cambridge University Press, 2005. 
Heidenheimer, Arnold J., and Johnston, Michael (Eds). Political Corruption: Concepts and Contexts. 3rd Edn, New Brunswick, Transaction Publishers, 2002.

Jalal, Ayesha. Democracy and Authoritarianism in South Asia: A Comparative and Historical Perspective. Cambridge, Cambridge University Press, 1995.

Karmakar, Madhusudan. Bubble: A Study of Scam, Scandal and Corruption in Indian Stock Market. New Delhi, Regency Publications, 1999.

Kashyap, Subhash C. Institutions of Governance in South Asia . Delhi, Konark, 2000.

Khan, Mushtaq, and Sundaram, Jomo Kwame (Eds). Rents, Rent-seeking and Economic Development: Theory and Evidence in Asia. Cambridge, Cambridge University Press, 2000.

Kidd, John B., and Richter, Frank-Jürgen (Eds). Corruption and Governance in South Asia. Basingstoke, Palgrave Macmillan, 2003.

Kumar, Arun. The Black Economy in India. New Delhi, Penguin Books, 1999.

Lal, Bhure. Corruption: Functional Anarchy in Governance. New Delhi, Siddharth Publications, 2002.

Lewis, David J. Corruption in Bangladesh: Discourse, Judgements and Moralities. Bath, Centre for Development Studies, University of Bath, 1996.

Mahbub-ul-Haq Human Development Centre. Human Development in South Asia 1999: The Crisis of Governance. Oxford, Oxford University Press, 1999.

Mitra, Chandan. The Corrupt Society: The Criminalization of India from Independence to the 1990s. New Delhi, Penguin Books, 1998.

Mitra, Subrata K. The Puzzle of India's Governance: Culture, Context and Comparative Theory. Abingdon, Routledge, 2005.

Oza, B. M. Bofors: The Ambassador's Evidence. Delhi, Konark, 1997.

Pai Panandiker, V. A. Problems of Governance in South Asia . Delhi, Konark, 2000.

Ray, Binayak. India: Sustainable Development and Good Governance Issues: A Case for Radical Reassessment. New Delhi, Atlantic Publishers and Distributors, 1999.

Transparency International. South Asia, Global Corruption Report 2004. London, Profile Books, 2004.

Vittal, N., and Mahalingham, S. Fighting Corruption and Restructuring Government. New Delhi, Manas Publishers, 2000.

Williams, Robert (Ed.). Explaining Corruption. Cheltenham, Edward Elgar, 2000.

Williams, Robert, and Theobald, Robin (Eds). Corruption in the Developing World. Cheltenham, Edward Elgar, 2000. 